\title{
RV 1-1
}

\section{Transmanubrial osteomuscular sparing approach (TMA) を用いた血管再建の工夫}

○河内 利賢、松脇 りえ、橘 啓盛、苅田 真、中里 陽子、田中 良太、長島 鎮、武井 秀史、 近藤 晴彦

杏林大学 医学部 外科学 (呼吸器·甲状腺)

【背景】胸腺腫は局所浸潤性が強く, 大血管合併切除と再建を必要とすることが多い腫瘍である，上大静脈再 建を行う場合, Temporary bypass を必要とすることがあり工夫が必要である.【症例】 77 歳女性, 検診で異 常を指摘され, 当院に紹介された. 前縦隔に $11.8 \times 7.1 \mathrm{~cm}$ 大の腫瘤が存在し, 左腕頭静脈は完全に閉塞して いた．右腕頭静脈から上大静脈（SVC）にも腫瘍の浸潤が認められた．CT ガイド下針生検で胸腺腫 Type A であった. 左内頸静脈は低形成でピンホール状であり, 右腕頭静脈をクランプした場合, 左腕頭静脈一右心 耳バイパスでは，脳血液還流が行われず，脳浮腫を来すことが予想された．このため，右鎖骨下静脈一右心 耳 Temporary bypass を選択した。この場合, 脳血液還流は右内䅡静脈から右腕頭静脈に還流するが, 右腕 頭静脈がクランプされると, 血流は右鎖骨下静脈に逆流し, バイパスを経由して右心耳に流入するため, 還 流が保持される.【手術】胸骨正中切開で前縦隔に到達した。 左腕頭静脈を末梢側で確保し, 結紮切離した. 心囊を開放し, 大動脈や心房・心室への浸潤がないことを確認した. TMA を施行し, 右腕頭静脈, 右内頚 静脈，右鎖骨下静脈を露出し，テーピングした，右鎖骨下静脈と右心耳間を人工血管でバイパスし，脳血液 還流を確保した. 右腕頭静脈, SVCをクランプ, 切離し, 腫瘍と一塊に摘出した. 右腕頭静脈-SVCを人工 血管で再建した後, Temporary bypass は縫合閉鎖，摘出した.【結語】浸潤性胸腺腫に対し，胸骨正中切開 と TMA で Temporary bypass を用いることにより切除し得た症例を経験した. 


\title{
RV1-2
}

\section{浸潤性胸腺腫抗がん剤治療後、左腕頭静脈閉塞症例に対し cross clamp 下での上大静脈置換術を施行した 1 例}

\author{
○松永 健志、鈴木 健司、高持 一矢、王 志明
}

順天堂大学 呼吸器外科

背景：縦隔腫瘍に対して上大静脈置換を行う時は、上大静脈の cross clamp 時間は文献的には 30 分前後が限 界とされている為、左腕頭静脈と右心耳にバイパスしてから施行するのが一般的である。症例：62歳、女性。 前医で CT ガイド下生検施行、胸腺腫、正岡 stage IVa（胸膜播種）の診断となり、ADOC を 6 コース施行、 外科的切除目的に当科紹介となった。術中所見として右胸膜播種は残存しており、完全切除は困難であった が、すでに左腕頭静脈は閉塞、今後、上大静脈を閉塞することが予想され、 salvage surgery (+volume reduction）目的に手術をすすめた。ほぼ閉塞していた左腕頭静脈を切離した。奇静脈弓より中枢まで腫瘍は上大 静脈に侵潤していたが、まず奇静脈弓より末梢で上大静脈を clamp して、つまり semi-cross clamp として、 右腕頭静脈と人工血管を吻合した。続いて、奇静脈弓より中枢の上大静脈で clamp、cross clamp として人工 血管と上大静脈を吻合した。合計 clamp 時間は 35 分、完全 cross clamp 時間は 18 分であった。術式は正中 切開から Hemiclamshell、縱隔腫瘍切除、上大静脈人工血管置換術、手術時間は 4 時間 49 分、出血量は $310 \mathrm{cc} 。$ 術後: 術直後に抜管、抗凝固療法などは使用せず、経過良好で第 9 病日に退院となった。まとめ: 前縦隔腫 瘍、左腕頭静脈閉塞症例に対して、cross clamp 下で工夫しながら上大静脈を再建したので報告する。 


\section{RV1-3}

\section{上大静脈置換を伴う縦隔睡瘍に対する手術加療の経験一血行再 建の工夫一}

○竹中 賢、小山 倫太郎、小林 健一、由良 讶希子、松宮 弘喜、篠原 周一、桑田 泰治、岡 壮一、 近石 泰弘、平井 文子、米田 和恵、田嶋 裕子、黒田 耕志、今西 直子、永田 好香、田中 文啓 産業医科大学 第2外科

血管浸潤を伴う縦隔腫瘍においては左腕頭静脈及び上大静脈の置換の手技が必要となる。それぞれの血行 再建の再建方法については諸説あり、上大静脈と左腕頭静脈の両方の血行再建が必要かどうかについては議 論のあるところである。今回我々は上大静脈置換を必要とした症例を 2 例経験し、一方は上大静脈と左腕頭 静脈それぞれを血行再建行い、もう一方は右心耳の癒着を認めたため血行再建に工夫を要した。症例 $1: 40$ 歳代男性、上大静脈浸潤を伴う縦隔型肺癌 c-T4N0M0 stage $3 \mathrm{~A}$ の症例にて手術加療を行った。術式は右上葉 切除 + 上大静脈切除・左右腕頭静脈切除 + 上大静脈再建 + 左腕頭静脈・右心耳バイパスを施行した。人工血 管は共に $10 \mathrm{~mm}$ の ring 付き人工血管を使用した。術後は抗凝固療法を施行したが、術後の CT にて左腕頭静 脈の閉塞が確認された。症例 $2: 70$ 歳代男性、周囲臟器浸潤を伴う巨大胸腺腫に対して右上中葉切除＋縦隔 腫瘍摘出術 + 上大静脈切除・左右腕頭静脈切除 +左右腕頭静脈〜 上大静脈血行再建術を施行した。血行再建 については ring 付き人工血管を用いて左右腕頭静脈から上大静脈を $\mathrm{T}$ 字状に再建を行った。術後 1 年の $\mathrm{CT}$ でも人工血管の閉塞は認めていない。人工血管を用いた血行再建を行うにあたっては血流を考慮した工夫が 必要であり、症例 2 においては遠隔期の閉塞も認めない結果であった。それぞれの血行再建について術中動 画を含めて報告する。 


\section{RV 1-4}

\section{浸潤型胸腺腫に対する上大静脈・睕頭静脈及び腕頭動眽置換術}

○坪地 宏嘉1、遠藤 俊輔1,2、滝 雄史 1 、峯岸 健太郎1、大谷 真一'、根岸 秀樹 ${ }^{2}$

'自治医科大学さいたま医療センター 呼吸器外科、自治医科大学 呼吸器外科

【はじめに】縦隔腫瘍に対する上大静脈合併切除後の静脈再建法は多様であり、グラフトの選択や適切な再建 法については議論の余地がある。また、動脈置換を併施した報告はまれである。浸潤型胸腺腫に対する上大 静脈・左腕頭静脈及び腕頭動脈の合併切除再建術を報告する。【症例】 64 歳女性。上大静脈症候群で当院を 紹介された。前縦隔に $8 \mathrm{~cm}$ の腫瘍を認め、上大静脈の右房流入部直上から静脈角近傍まで血管の内腔は腫瘍 で閉塞していた。胸腺腫の診断で胸骨正中切開下に手術を施行。左静脈角の約 $1 \mathrm{~cm}$ 中枢側で左腕頭静脈を斜 めに切離した。 $8 \mathrm{~mm}$ の $\mathrm{ePTFE}$ グラフトを斜めにトリミングし左腕頭静脈とパラシュート法で吻合した。静 脈の捻れや屈曲を防止するため吻合部を斜めにした。中枢側も同様にグラフトを斜めにトリミングして右心 耳に吻合した。腫瘍は大動脈弓部から右腕頭動脈及び総頚動脈に広範に接していた。大動脈と総澒動脈から

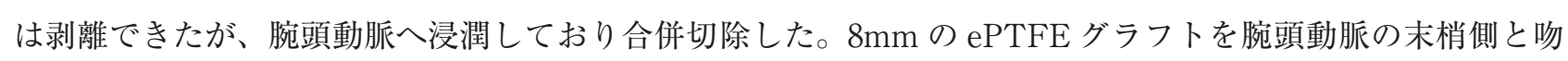
合し、さらに上行大動脈をサイドクランプした後に切開し人工血管と縫合した。腫瘍が上大静脈内腔を占拠 し右房近傍まで及んでおり、右腕頭静脈と上大静脈の間の血管置換は行なわず、左側のみのバイパスとした。 奇静脈、右腕頭静脈、上大静脈を順次切離して腫瘍を摘出した。術中及び術後にヘパリンを投与し、経口摂 取開始後ワーファリンに変換した。術後の人工血管の開存は良好であった。【結語】上大静脈置換後の左側の バイパスは、長いことと吻合部の捻じれなどにより閉塞をきたしやすいが、血管とグラフトとを斜めに吻合 するなどの工夫により防止できる。 


\section{RV 1-5}

\section{右腕頭静脈-右心耳一時的バイパス下に上大静脈切除・再建を 行った浸潤型胸腺腫の 1 切除例}

○鈴木 浩介、北見 明彦、林 祥子、大橋 慎一、佐野 文俊、植松 秀護、鈴木 隆 昭和大学横浜市北部病院 呼吸器セン夕ー

上大静脈合併切除を要する胸腺腫瘍の手術に際しては, 同静脈の遮断時間あるいは遮断時の還流静脈血流 のバイパス法などが問題となる。今回我々は、左腕頭静脈-右心耳バイパスが困難で、また上大静脈単純遮断 後の静脈圧上昇のため、右腕頭静脈-右心耳一時的バイパス下の上大静脈切除・再建を要した胸腺腫の 1 例を 経験したので報告する。

症例； 42 歳女性。動悸、立ちくらみ、顔面の浮腫を主訴に前医を受診し、胸部 X-p にて右肺門部腫瘤影を指 摘され当院へ紹介受診となった。胸部 CT 上、最大径約 $10 \mathrm{~cm}$ の前縦隔腫瘍を認め、左腕頭静脈から上大静 脈の著明な狭窄を認めた。CT ガイド下針生検を施行し、胸腺腫 TypeB2 の診断となった。ステロイドセミ パルスを施行したところ腫瘍の縮小を認めたが、約 2 週間の経過で再増大を認めた。手術は胸骨正中切開 + 右前方開胸にて行った。右内䅡静脈より術中静脈圧モニタリングを行った。左腕頭静脈は腫瘍に取り囲まれ、 末梢側の血管径も細く再建は困難であった。奇静脈は温存可能であり、その末梢側で上大静脈をクランプし たが、䅡静脈圧の著明な上昇を認めた。右腕頭静脈から脱血し、右心耳に送血を行う一時バイパスを置き、 遠心ポンプにて血流を維持し、上大静脈を切除した。右肺上中葉の温存も困難であり、腫瘍と一塊に右上中

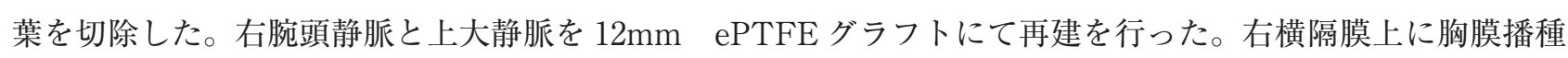
病巣を認め腫瘍切除を行った。手術時間は 10 時間 54 分、遠心ポンプ装着時間 180 分。出血量は $1584 \mathrm{ml}$ であ り術中 RCC $1400 \mathrm{ml}$ の輸血を行った。右腕頭静脈-右心耳一時的バイパスは、脳圧上昇の予防に加え、肺葉切 除時の肺門部視野の確保の上で有用であった。 


\section{RV 1-6}

\section{SVC 人工血管置換術を行う際に、右心耳を剥離し右心房壁よ り出血し修復を要した 1 例}

○黒田 耕志?、篠原 周一'、小山 倫太郎?、小林 健一'、由良 冴希子'、松宮 弘喜?、桑田 泰治? 竹中 賢?、近石 泰弘'、岡 壮一'、平井文子'、米田 和恵'、田嶋 裕子'、永田 好香?、今西 直子'、 西村 陽介²、田中 文啓

'産業医科大学 第2外科、㦃業医科大学 心臟血管外科

症例は 68 歳、女性。左乳癌に対して左乳房切除、リンパ節郭清術後、 2 年で右転移性肺腫瘍に対して右肺 上葉部分切除を施行。社会的事情により化学療法は拒否、ホルモン療法は中断していた。当院受診時、縦隔 腫瘍が増大し、左腕頭静脈は完全閉塞、上大静脈も閉塞しかけており、頸部および左上肢の腫脹を認めた。 また、右肺上葉部分切除断端に結節を認め、再発が疑われた。縦隔腫瘍切除、左腕頭静脈と右腕頭静脈一上大 静脈合併切除、右肺上葉切除を行った。再建は左腕頭静脈から右心耳および右腕頭静脈から上大静脈への人 工血管置換術を行った。右心耳が小さく、また右心耳の先端が右心房前面の脂肪組織と癒着していたため、 剥離すると冠状溝の右心房壁から出血したため、縫合を繰り返し止血した。病理組織学的には乳癌の縦隔り ンパ節転移であった。SVC 症候群は改善したが、術後 5 日目にMRSA 縦隔炎を合併し右開胸創よりドレナー ジ、その後の抗菌薬にて軽快した。まとめ: 右心耳を剥離する際には、心膜の折り返しが近いことがあり、 右冠動脈も近傍の脂肪組織の中を走行しているため、深く剥離するのは危険である。また、右心耳を血管鉗 子にて把持、縫合を行う際には、右冠動脈や三尖弁の弁輪、洞結節が近く、部位や方向に注意が必要である。 縦隔炎を合併した場合、胸骨正中創を開き、洗浄ドレナージ、大網充填が考えられるが、今回の症例では吻 合部への脂肪組織の充填、早期の右開胸創ドレナージ、抗菌薬により、胸骨骨髄炎を発症せず、感染を制御 できたことが考えられた。 


\section{RV2-1}

\section{気管支原発カルチノイドに対して肺実質切除を伴わない右上中 間幹分岐部切除を行い、2 連銃再建を行つた 1 例}

○青景 圭樹、仲宗根 尚子、市川 智博、後藤 真輝、秦 一倫、関原 圭吾、三好 智裕、菱田 智之、 吉田 純司、坪井 正博

国立がん研究センター東病院 呼吸器外科

48 歳女性。咳嗽を主訴に近医受診した。右上葉気管支と中間気管支幹の分岐部に腫瘤を認め、当科紹介受 診となった。腫瘍は右上葉気管支と中間気管支幹分岐部の中間気管支幹側に存在していた。中間気管支幹の 末梢側への気管支鏡挿入が困難であったため、スネアで腫瘍を一部切除し、未梢気道の開存を確認した。中 間気管支幹の末梢側は intact であった。病理学的に定型カルチノイドの診断であった。CT 上明らかな肺実 質浸潤を認めず、リンパ節腫大も認めなかった。cTlaN0M0 stageIAのカルチノイドの診断で手術を行った。 術中所見では、腫瘍部の気管支壁に軽度の膨隆を認めたが、明らかな肺実質浸潤を認めず、\#11s リンパ節の 腫大も認めなかったため、十分な切除マージンを確保しつつ、肺実質温存の右上中間幹分岐部切除を行い、 上葉気管支と中間気管支幹の右主気管支への 2 連銃再建を行った。手術時間 3 時間 12 分で出血量は $50 \mathrm{ml}$ あった。術後合併症を認めず、第 7 病日に退院となった。術後の気管支鏡も吻合部の開存は良好であった。 手術ビデオを供覧し、本術式について考察する。 


\section{RV2-2}

\section{左主気管支切除再建を左開胸で施行した 2 例一解剖学的相違と 視野確保のための工夫一}

$\bigcirc$ 平井 文子、小山 倫太郎、小林 健一、松宮 弘喜、篠原 周一、桑田 泰治、竹中 賢、近石 泰弘、 岡 壮一、米田 和恵、黒田 耕志、今西 直子、田中 文啓 産業医科大学 第2外科

【はじめに】肺葉切除を伴わない左主気管支切除は比較的珍しい術式であり、そのアプローチは病変の首座や 施設によって様々である。左開胸によるアプローチでは縦隔の深部で縫合する必要があり、その視野確保に は難渋する。【症例 1】18 歳、女性。他疾患精査時の CT で左主気管支入口部に膜様部から隆起する病変を認 め、90\%の狭窄を認めた。気管支鏡下にスネアで切除し、mucoepidermoid carcinoma と診断し、手術の方針 とした。腫瘍は左主気管支の根部で大動脈の裏に存在し、気管の左壁の追加切除も必要であった。大動脈、 気管をテーピングして気管支の授動を行った。手術時間 5 時間 35 分、出血 130ml。【症例 2】 80 歳、男性。2009 年の直腸癌の術後、2014 年にCT で気管分岐下リンパ節腫大と左主気管支浸潤を認めた。気管支鏡では、carina より2 ring 末梢に左主気管支を $80 \%$ 占拠する腫瘍を認めた。他に病変はなく手術の方針とした。この症例は 大動脈が背側に大きく湾曲し、比較的肺門部の視野が良好であった。さらに気管をテーピングすることで右 主気管支まで視野が確保できた。手術時間 4 時間 30 分、出血 $120 \mathrm{ml}$ 【結論】左主気管支切除再建を左開胸 で施行した 2 例を経験した。年齢により縦隔の柔軟性や血管、気管の石灰化など違いや解剖学的相違がある ため、同じような病巣でも手術視野が大きく異なる。それぞれの解剖学的特徴を見極め、操作を工夫するこ とで、十分な視野で安全に操作を行えた。 


\title{
RV2-3
}

\section{胸腺癌合併気管カルチノイドに対する Barclay 法による分岐 部再建}

\author{
○山田 健、水野 幸太郎、松井 琢哉
}

刈谷豊田総合病院 呼吸器外科

【はじめに】分岐部再建術は術中呼吸管理、術後気道合併症が危惧される。今回胸腺癌合併気管カルチノイド に対して一期的に手術を施行した症例を経験した。【症例】 57 歳男性、B.I. 1400。左肺炎治療中にCTにて 2.6 $\mathrm{cm}$ 大の前縦隔腫瘍と分岐部気管膜様部に $7 \mathrm{~mm}$ 径の気管ポリープを指摘された。ポリープは生検でカルチノ イドと診断された。後側方開胸による一期的手術を予定した。【手術】 $20 \mathrm{~cm}$ の聴診三角開胸 (muscle sparing thoracotomy)、第 5 肋間筋弁を作成後肋骨を背側で切離し開胸した。胸腔鏡下に胸腺胸腺腫摘出術を施行中 左腕頭静脈から出血を認めたため、手術台を $45^{\circ}$ 背側にローテートし胸骨正中切開を加えた。腫瘍は左腕頭 静脈に浸潤しており、クランプ後部分合併切除し縫合閉鎖した。続いて分岐部切除再建に移った。腫瘍を含 め膜様部を舟状に切除。HFJV を使用し一期的縫合閉鎖した。しかし左主気管支入口部断端陽性であったた

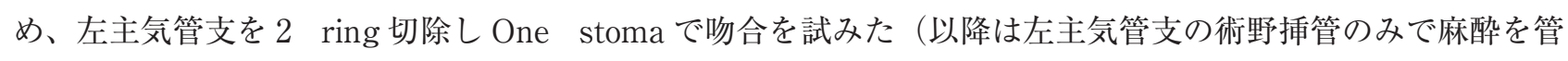
理)。膜様部に tension がかかり吻合を断念。Barclay 法が最も tension がかからないと判断。右主気管支を 1 ring、気管を 4 ring 切除し 4-0 PDS II 11 針で縫合 (左側と膜様部は連続縫合)。第 1 吻合から 4 ring 離した 中間幹左側軟骨部に四角に側孔を開け左主気管支と 11 針で結節吻合を行った。肋間筋弁被覆後も第 2 吻合部 から少量の air leakage を認めたが治癒可能と判断し、手術室にて気管 tube の抜管を行った。翌日には air leakage は消失。5 病日で抜管。9 病日で退院となった。術後合併症なく、気管支鏡検査で吻合部の血流は良好で あった。胸腺は扁平上皮癌、気管は定型カルチノイドであった。 


\title{
RV2-4
}

\section{輪状軟骨部分合併切除を伴う気管管状切除 再建訹の実際}

\author{
○永島 宗晃、清水 公裕、大瀧 容一、尾林 海、中澤 世識、矢澤 友弘、大沢 郁、東 陽子、
} 飯島 岬、矢島 俊樹、茂木 晃、桑野 博行

群馬大学医学部附属病院 外科診療セン夕一 呼吸器外科

気管病変に対しては主に気管管状切除が選択されるが，その適応症例数は限られており外科医全員が多数 例経験し技術を習熟することは難しい，本術式においては手術戦略が重要であるが，技術的には基本手技が 中心であり難易度は決して高くはない。しかし輪状甲状軟骨近傍までの操作が必要になった場合は，両側反 回神経と喉頭の解剖学的位置関係に留意しながら繊細な手術操作をしなければならず難易度は格段に高くな る. 本術式のポイントは反回神経の温存であり，鋭的剥離操作によりいかに末梢まで同神経を同定できるか である。また吻合の際には厚く，膜様部のない輪状軟骨と気管との形状の違いを認識しつつ，運針を行わな くてはならない，今回，当科で経験した輪状軟骨部分合併切除を伴う気管管状切除症例を video で供覧しつ つ, 手術操作の knacks and pitfalls について論じたい.【症例】46 歳, 女性，喘鳴及び呼吸困難感の増悪にて 紹介となった，気管支鏡検査で輪状軟骨直下に pinhole 状の著明な狭窄を認め，㓔痕性肉芽腫などが疑われ た．頝部襟状切開でアプローチ．気管鞘で気管を剥離後，外側に残した層状の結合組織の中から反回神経を 同定，さらに末梢に向かって剥離を進め，輪状軟骨に放射状に分布するところまで確認した．その後気管内 腔を確認しつつ第 $1 / 2$ 気管軟骨輪及び輪状軟骨右側の部分合併切除を行った．吻合は 4-0 モノフィラメント 吸収糸 12 針を用いて結節縫合で再建した。手術時間 169 分，出血量 $216 \mathrm{ml}$. 術後反回神経麻痺認めず，術後 8 病日目に軽快退院．最終病理診断で IgG4 関連疾患の疑いであったが，血液生化学検査上，IgG4 を含め自 己免疫関連の異常は認めなかった。 


\section{RV2-5}

\section{転移性気管腫場に対して気管管状切除十喉頭部分切除再建を施 行した 1 例}

$\bigcirc$ 矢口 綾子、目井 秀門、阿部 創世、永田 旭、宮原 尚文、宮原 聡、吉田 康浩、濱武 大輔、 平塚 昌文、山下 眞一、白石 武史、岩㟝 昭憲

福岡大学病院 呼吸器乳腺内分泌小児外科

【はじめに】気管腫瘍に対する気管管状切除・喉頭切除再建では吻合部にかかる緊張を減らすために切除長に より再建の工夫が必要となる. 今回我々は long gapの気管管状切除 + 喉頭部分切除に対する再建術を経験し たため，手技の工夫をビデオで供覧する。【症例】 66 歳, 男性.【既往歴】16 年前に左腎細胞癌に対して左腎 摘出を施行. 3 年前に右甲状腺転移に対し甲状腺右葉切除施行. 【現病歴】血痰を主訴に当院受診した. CT 検查・気管支鏡検査で輪状軟骨直下〜第 3 気管軟骨部の気管腫瘍を指摘された．腎細胞癌の気管転移再発が 疑われ手術の方針となった。【手術所見】全身麻酔下, 澒部襟状切開で手術を開始した。腫瘍は前澒筋群・甲 状腺左葉に浸潤しており，甲状軟骨下端から第 3 気管軟骨まで存在していた，術野挿管を行いながら甲状軟 骨下端の一部〜第 4 気管軟骨まで管状切除した。切除長は $6 \mathrm{~cm}$ であった．甲状腺左葉・前澒筋群は合併切除 した. 再建は laryngeal release および hilar release を併用することで緊張なく喉頭気管吻合が可能であった.

【術後経過】術後 3 日目に挿管チューブの抜管を試みるも上気道狭窄が出現し気管切開を行った. その後声門 下狭窄への対策として T-tube stentへの入れ替えを行った，術後嚥下機能低下・嗄声が見られたが，嚥下訓 練・発声練習を行い, 術後 8 ケ月現在良好な嚥下能力・発声を得ることができている. 
RV2-6

\section{ムコ多糖症による気管軟化症を伴った気管切開後の気道狭窄に 対して縦隔気管孔を形成した一例}

○近石 泰弘、小林 健一、松宮 弘喜、篠原 周一、竹中 賢、岡 壮一、黒田 耕志、今西 直子、 浦本 秀隆、田中 文啓

産業医科大学 第2外科

【症例】16 歳男性。ムコ多糖症 II 型（ハンター症候群）として治療中されていた。 5 年前（11 歳時）に原疾 患による喉頭狭窄に対して気管切開が施行された。2 週間前に呼吸苦出現。その 5 日後に呼吸苦増悪し、前 医に救急搬送。精查にて気管切開後の肉芽による気道狭窄を認め、人工呼吸器管理のまま当科に紹介となっ た。ムコ多糖症による巨舌、扁桃腫大、気管軟化により、肉芽部の観察が困難であったため、気道確保のた め、縦隔気管孔を形成する方針とした。また、術中に換気不良になる可能性もあるため、経皮的人工心肺補 助下（PCPS）にて手術を行うこととした。【手術所見】右鼠径部から PCPSにて体外補助循環を確保。鎖骨 から胸部にかけてU 字フラップを作成。胸骨を第 $1 、 2$ 肋軟骨から切除し、胸骨柄も含めて切除。腕頭動静 脈の頭側で気管を確保し、縦隔気管孔の形成に最低限必要な長さを残して気管を切除。切除部より末梢に肉 芽の残存を認めたが、換気は可能と判断。気管と皮膚の縫合の緊張緩和のため、両鎖骨骨頭は切除。縦隔気 管孔の皮膚は血流を保つため、電気入スを使用せずに、鋭的に皮膚の孔を作成。腕頭動静脈と気管の間に胸 腺を充填し、縦隔気管孔を形成した。気切孔より口側の気管断端を摘出し、喉頭分離を行った。【術後経過】 術後は人工呼吸器にて管理し、術後 19 日目に人口呼吸器離脱。術後 1 ケ月半で自宅に退院となった。【まと め】先天性疾患に対する気管切開後の肉芽による気道狭窄の治療は様々な理由により、難渋することが多い。 今回、ムコ多糖症を基礎疾患とした気管切開後の気道狭窄に対して縦隔気管孔を形成することにより気道確 保が可能であった一例を経験したので報告する。 


\section{RV3-1}

\section{完全鏡視下解剖学的右肺 S*区域切除+S9 部分切除}

清水 公裕、永島 宗晃、大瀧 容一、尾林 海、中澤 世識、矢澤 友弘、東 陽子、飯島 岬、 矢島 俊樹、茂木 晃、桑野 博行

群馬大学医学部附属病院 外科診療セン夕一 呼吸器外科

S*は S6 と S10 の間に存在する副区域であり、右肺での存在頻度は、山下ら $28 \%$ 、Boyden ら $48 \%$ と報告 により様々である。実臨床においても、肺葉切除を行う場合には術式には影響しない区域であり、術中所見 でも $\mathrm{S}^{*}\left(\mathrm{~B}^{*}\right)$ を認識することは極めて難しいため、その認知度は低い。しかし、区域切除の必要性が増した 現状に㧈いて、S*の存在とその認識は、S*区域切除ではもちろんのこと隣接する S6 及び $\mathrm{S} 10$ 区域切除を行う 上で極めて重要である。これまでに、我々は右肺下葉 271 例の 3DCT を解析し、 $\mathrm{S}^{*}\left(\mathrm{~B}^{*}\right)$ は 271 例中 69 例 (25.5\%) に存在し、全てが single stem であることを確認した。さらに、転移性肺腫瘍 1 例、肺クリプトコッカス症 1 例に対して完全鏡視下に $\mathrm{S}^{*}$ 単独区域切除を行い $\mathrm{S} 6$ と $\mathrm{S} 10$ の間に明瞭な区域間を有する $\mathrm{S}^{*}$ 副区域が存在する ことも確認している。したがって、 $\mathrm{S}^{*}$ を意識すること無く、 $\mathrm{S}^{*}$ の結節を $\mathrm{S} 10$ と誤認し、B10を jet ventilation した場合、結節が存在する $S^{*}$ 副区域が inflation されず、区域の設定に困惑する可能性がある。逆に、術前 3 DCT で $\mathrm{S}^{*}$ 認識していれば、S6c や S 10a など $\mathrm{S}^{*}$ と近接する区域に結節が存在した場合、含気虚脱法で $\mathrm{S}^{*}$ inflation させることで surgical margin が十分に確保された S6 または S10+S*区域切除が可能である。そこで 今回我々は S*区域の局在や頻度、解剖学的バリエーションを $3 \mathrm{DCT}$ とビデオを用いて解説すると共に、完全 鏡視下で行った転移性肺腫瘍に対する完全鏡視下 $\mathrm{S}^{*}$ 単独区域切除（+ S9 部分切除）のビデオを供覧し、術式 の詳細と Knack and Pitfalls について述べたい。 


\section{RV3-2}

\section{Hybrid VATS による右肺 S8+9 切除と術後肺門リンパ節転 移陽性に対する追加下葉切除}

○宮田 義浩、三村 剛史、津谷 康大、伊藤 正興、黒川 知彰、甲斐 佑一郎、鍵本 篤志、岡田 守人 広島大学 腫瘍外科

【目的】我々は肺野末梢 cTlaN0M0 肺癌に対して区域切除+選択的リンパ節廓清を行っている。術中迅速でリ ンパ節転移陽性例は肺葉切除にコンバートする。今回右 S $8+9$ 切除後に術後病理で $\mathrm{pN} 1$ が明らかとなり、completion lobectomy を追加した症例を経験したので、初回手術、追加手術をビデオで供覧する。【症例ビデオ】50 歳代男性、S8 に存在する $14 \mathrm{~mm}$ 大の solid tumor に対して S8-9 区域切除を、 $1 \mathrm{~cm}$ のカメラポートと $5 \mathrm{~cm} の$ 小開胸より行った。切除予定区域枝（B8，9）を同定し、肺門で区域間静脈（V9b）を末梢まで露出する。肺 末梢区域間の目印として切除区域 (S8，9)を含気させた後、これに沿って肺門中枢で作成した区域面に向かっ て連続させるよう、立体的にイメージしながら電気メスを用いて肺実質を切離する。最後に残った V8 を切 離して S8，9切除を終了した。区域間面はネオベールシートとボルヒールで被覆した。本症例では\# $12 \mathrm{~L}, 11 \mathrm{i}$ の一部を術中迅速に提出し陰性を確認した。しかし術後病理で\#11iに $\mathrm{pN} 1$ が判明したため、術後 1 か月後に completion lobectomyを追加した。肺門や胸壁には強固な癒着が認められたが、被覆された区域間面には癒 着が無かった。残存肺葉内リンパ節に転移を認めなかった。当科の過去 7 年間のデータでは、術中リンパ節 転移陽性（cN0 $\rightarrow \mathrm{sN1} 1-2 ）$ のため術中肺葉切除にコンバートした症例は $5 / 228$ 例 $(2.2 \%)$ 、術後リンパ節転移 陽性（cN0 $\rightarrow \mathrm{pN} 1-2 ）$ は $3 / 228$ 例（1.3\%）で、本症例を含む 2 例に Completion lobectomy を追加した。【結語】 肺癌に対する根治的区域切除には慎重な術中リンパ節評価が必須であるが、術後に判明した転移陽性例には completion lobectomy も考慮すべきである。 


\section{RV3-3}

\section{ICG 蛍光法を用いた胸腔鏡下右 S9+10 区域切除術〜手術の 工夫と実際〜}

○野間 大督、文 敏景、平田 佳史、中島 拓也、山崎 宏継、平井 慶充、松浦 陽介、中尾 将之、 中川 健、奥村 栄

がん研究会有明病院呼吸器センター 外科

【はじめに】S9+10 区域切除術を要する症例は比較的稀であり、胸腔鏡下に行う場合はピットフォールが存在 する。【目的】当科で行っている胸腔鏡下右 $\mathrm{S} 9+10$ 区域切除の術前解剖学的評価、手術時の工夫について供 覧する。【方法】当院では 2013 年 1 月から VINCENTによる肺血管、気管支の 3D 解析が可能となり積極的 に術前解剖学的評価を行っている。術前のチェックポイントは margin 確保の問題として (1) V $6 \mathrm{~b}+\mathrm{c}$ と腫瘤 との距離、（2） V8b と腫瘤との距離、（3）S6 区域間形成のメルクマールとなる $\mathrm{V} 6 \mathrm{~b}+\mathrm{c}$ の股と、 B6, B9+10 分岐（A6， A9+10 分岐）との位置関係、（4）切離する PV 選択のための V8b（又は残すべき S8 へ向かう枝） の分岐の高さと、B8、B9 との位置関係の把握が特に重要である。右 $\mathrm{S} 9+10$ 区域切除術の手順は、1）S6 と の区域間形成を先行、2）葉間区域間から区域動脈、気管支の処理、3）底区を尾側に展開した視野で肺静脈 の処理、4）S7，8 との区域間形成、である。S6 との区域間形成を先行することにより、開けた視野での区域 肺動脈、気管支の処理が可能であり、比較的末梢でのこれらの処理が可能となる。さらに肺動脈、気管支処 理後は、肺を尾側に展開することにより肺静脈末梢の解剖学的評価が容易となり、真に切離すべき肺静脈と 残すべき肺静脈を選択しつつ処理を行う事ができる。S6 区域間形成を先行するには術前の（3）の評価が非 常に重要となってくる。また、2 度の区域間形成に先だって ICG 蛍光法による区域間形成ライン描出を行っ ている。当方法は肺虚脱の状態で簡便かつ複数回にわたり区域間が描出できる利点がある。実際の手術手技 についてビデオを供覧し発表する。 


\section{RV3-4}

\section{右 S6/底区の区域間形成を利用した胸腔鏡下右 S 10 区域切除 の 1 症例}

○黒田 浩章、飯塚 修平、出嶋 仁、瀬戸 克年、直海 晃、水野 鉄也、坂倉 範昭、坂尾 幸則 愛知県がんセンター中央病院 呼吸器外科

【背景】末梢小型肺癌に対する JCOG1211 臨床試験の登録集積が終了し、結果次第で区域切除＋肺門リンパ節 郭清が標準治療となる可能性がある。本来、肺の切除量を少なくし機能温存を目的とした区域切除術では、 術創も低侵襲に行えることが理想である。当科で行っている完全胸腔鏡下区域切除に扔ける手技の工夫と実 際について供覧する。【症例】66 歳、女性。JCOG1211 登録症例。GGO（肺野条件径 20mm, Consolidation 10 $\mathrm{mm}$, 縦隔条件径 $0 \mathrm{~mm}$ ）に対する完全胸腔鏡下右 S10 区域切除を予定した。【手術システム】一方を倒立さ せた対面式モニターを患者頭側に 2 台設置、術者は患者の背側に立つ。 4 ポート（右手 $20 \mathrm{~mm}$ 、左手 $7 \mathrm{~mm}$ 、 カメラ $10 \mathrm{~mm}$ 、助手 $15 \mathrm{~mm}$ ) を設置し、手術操作はモニター視のみで行った。術前 CT の sagittal/coronal view, 3D reconstruction を用いて腫瘍の局在と血管の走行を把握した。【手術手順】葉間から肺動脈を露出し，A6・ $\mathrm{A} 7$ A10 を確認後、その中枢側に隣接する B6, V6 を露出する. 背側で下肺静脈露出後に, $\mathrm{V} 6 \mathrm{~b}+\mathrm{c}$ を末梢ま で露出する．再度葉間から $\mathrm{V} 6 \mathrm{~b}+\mathrm{c}$ の尾側で背側にトンネリングする．S6 と底区域間を自動縫合器で形成し た後、さらに A10 を切離すると、B10 さらにその縦隔側に S10 から灌流する肺静脈と S9/S10 間の V $9 b$ を容 易に同定できる。最後に ICG を用いて S9-S10 区域間を同定・マーキングした。肺勒带・ICG・S6/底区間を メルクマールに自動縫合器で区域間を形成した。時間 216 分、出血 40ml。【結語】S10 区域切除に対して、S 6/底区間形成は、S10 から灌流する肺静脈同定に有用である。また自動縫合器の頭側の出口となるため区域 間面形成にも利用できる。 


\title{
RV3-5
}

\section{VINCENT とICG の気管支注入および近赤外線胸腔鏡の使用 による解剖学的右 S2+S 1 a 拡大区域切除}

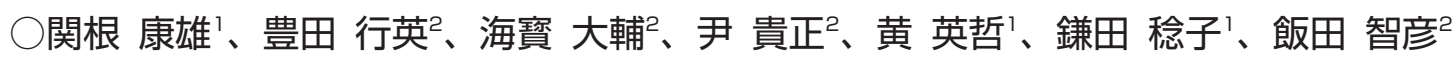
'東京女子医科大学八千代医療セン夕一 呼吸器外科、2君津中央病院 呼吸器外科

【目的】肺区域切除における胸膜切離線の決定は、通常肺門部の血管・気管支を処理した後、含気虚脱法や肺 表面の虚血状態を観察して決定する。しかし拡大区域切除では、亜区域枝や正確な切離線の同定が困難とな る場合がある。今回我々は、術前に volume analyzer synapse VINCENTにて複数の区域切除のシミュレー ションを行い、それぞれの切離 margin の距離を基に切除範囲を決定した。そして麻酔導入時に経気管支的 に ICG を切除予定区域/亜区域枝に注入し、近赤外線胸腔鏡にて胸膜切離線を同定することで、解剖学的に 正確な拡大区域切除を行う方法を確立したので報告する。【症例】症例は 73 歳女性。右上葉 $\mathrm{S} 2$ に $21 \times 12 \mathrm{~mm}$ 大の GGO を指摘された。術前にVINCENTを用いて S2a, S2, S2+S1a, S2+S3, S2+S1a+S3a の区域切除 simulation を行い、腫瘍から切離面までの距離が $26.7 \mathrm{~mm}$ であった $\mathrm{S} 2+\mathrm{S} 1 \mathrm{a}$ を選択した。麻酔導入時領域気管支 （rt. B1a，B2ai，B2aii，B2bi，B2bii）に10 倍希釈 ICG+air 400mlをそれぞれ注入した。手術開始時に近赤 外線胸腔鏡にて胸腔内を観察すると、ICG 注入領域の蛍光が観察され、stapler を区域間切離に用いず、解剖 学的 S2+S1a 拡大区域切除を完遂した。摘出標本では $32 \mathrm{~mm}$ の margin が得られた。術後 CTにて B1b 㧤よ びB3 の残存が確認され、術後 6 ケ月での肺機能および肺容量ともほぼ術前值を示していた。【結論】本法は 十分な切離マージンを確保できる区域切除法と考えられた。 


\title{
RV3-6
}

\section{サージカルマージン確保を意識した小型肺畽瘍に対する完全鏡 視下区域切除（DONUTS method）}

\author{
○西田 達、三上 厳、藤井 祥貴、秋月 克彦
}

石切生喜病院 呼吸器外科

【緒言】小型肺腫瘍に対し、胸腔鏡下肺区域切除を選択せざるを得ないことがあるが、十分なサージカルマー ジンを確保する方法は一定の見解を得ない。我々は以前よりサージカルマージン確保のための新技術（DONUTS method : Dual Outline of Navigating Utensil in Thoracoscopic Segmentectomy method）を考案し [Nishida T, Eur J Cardiothorac Surg. 2015]、完全鏡視下肺区域切除を行っており、転移性肺腫瘍に対する左 $\mathrm{S} 6$ 切除、原発性肺癌に対する右 S3 切除をビデオで紹介する。【理論】 $2 \mathrm{~cm}$ 以下の小型肺腫瘍の場合、十分な サージカルマージンは、腫瘍辺縁から腫瘍最大径以上離れた領域と規定し、中心点が腫瘍中央と一致する球 体（直径=腫瘍最大径 $\times 3$ ）を想定する。そして責任区域肺動脈基部を頂点、臓側胸膜面を底面としてこの球 体を内接し得る円錐体を構築し、解剖学的区域にこの円錐体を加えることで十分なサージカルマージン確保 となる。【手技】円錐体底面と同じ大きさのシート（DONUTS sheet）を作成し、円錐体底面を可視化して区 域間切離を行う。まず MPR 可能な thin slice で撮影後、円錐体底面の中心にあたる臓側胸膜面に、安全性を 重視した胸膜穿刺を行わない方法で CT ガイド下マーキングを行う。次いで解剖学的区域切除に準じ、責任 区域動脈、区域間静脈の切離を行った後、含気虚脱線を描出し気管支を切離する。区域間切離は中心部をマー キングに合わせ貼布したDONUTS sheetを利用し、含気虚脱線を超えた領域まで行い完全鏡視下区域切除を 行う。【結語】簡便かつ安全に行える DONUTS methodを利用することで、小型肺腫瘍に対して十分なサー ジカルマージンを確保した完全鏡視下肺区域切除が行える。 


\section{RV4- 1}

\section{肺癌に対するロボット手術の実際と最近の工夫}

○谷口 雄司、荒木 邦夫、三和 健、松岡 佑樹、若原 誠、万木 洋平、大島 祐貴、中村 廣繁 鳥取大学 胸部外科

【はじめに】当院では，2011 年 1 月より肺癌に対するロボット手術を開始しており，われわれのおこなって いる手術手技を供覧する.【対象】 2015 年 11 月までに当科で施行した肺癌に対するロボット手術は 41 例で, 全例臨床病期 $I$ 期で，術式は区域切除 1 例，肺葉切除 36 例，気管支形成を伴う右上葉切除 1 例であった.【手 術手技】Wound retractor を用いた 3 アーム+1アシストで開始し，ロボットの操作に慣れた後，4アーム+ 1アシストに移行した。また，小柄な体格でもワーキングスペースを確保するために CO2 送気を併用した Completely portal robotic lobectomy（CPRL）と変遷した.【最近の工夫】CPRLでは，1）葉間形成や血管 の切離における自動縫合器の方向がアシストポートからでは最適でない場合, $8 \mathrm{~mm}$ のロボットアーム用ポー トを $12 \mathrm{~mm}$ のポートに入れ替える必要性が生じる，2）胸腔内を吸引すると肺が再膨張して視野が不良とな

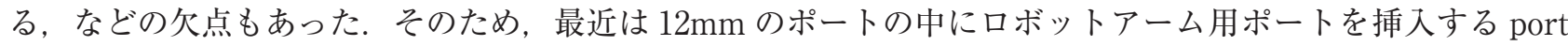
in port technique を導入することで，容易にロボットアーム用ポートを抜去して自動縫合器を挿入すること が可能となった．また，バルブレスで胸腔内圧を一定に維持することが可能なエアシールを導入することで, 必要時に胸腔内の吸引が常時可能となった。さらにロボット専用の Vessel Sealer を用いることで良好な環境 下での手術が㧍こなえている。【注意点】コンソールドクターと術野に入っている助手との意思疎通を十分に はかること，モニターに映らないロボットアーム同士の干渉やロボットアームと助手の道具の干渉などに十 分注意することが, トラブルを回避するために重要と考えている. 


\section{RV4-2}

\section{内視鏡用ホルダ EMARO ${ }^{\circledR}$ 用いた胸埶鏡手術の経験}

○神谷 紀輝、蛭川 和也、関 大仁、金田 宗久、鈴木 慶一、石井 良幸、浅沼 史樹、大作 昌義 北里研究所病院 外科

【目的】本邦で開発された内視鏡ホルダ $\mathrm{EMARO}^{\circledR}$ を用いた胸腔鏡手術の使用経験について検討した。【結果】 事前にデモ機での操作を経験後に手術 7 日前に機械を搬入し術前に内視鏡器械の装着を確認した。手術室又 タッフに対しても機械搬入前後の 2 回オリエンテーションを実施した。肺癌、転移性肺腫瘍、縦隔リンパ節 腫大症例に適応として右上葉部分切除、右下葉切除、リンパ節生検を実施。このなかで最後の症例はホルダ に固定された状態では胸腔鏡のポートへの挿入角度の制限が生じる関係で使用不可能であった。あらゆる方 向での胸腔鏡固定の安定性、自由な操作性は非常に優れていた。本体アーム部分が患者の真上にセットされ るが、器械の受け渡しやモニター視に著しい障害とはならなかった。安全性も含め突発的なトラブルは経験 しなかった。当院で実施されている胸腔鏡手術は第四胁間の後腋窩線上に観察ポートを増設するために、胸 腔鏡と水平軸との織りなす角度（挿入角度）は多くの場合、垂直方向に近くなる。内視鏡ホルダを用いた胸 腔鏡操作では 47 度までの制限があるために、胸壁の厚い体型では使用困難であった。ヘッドセンサーに連動 した動きは概ね良好であったが、フットスイッチによるアクティベーション操作を伴うためスイッチ操作が やや煩雑になり慣れが必要であった。【考察】今後いくつかの改良点が挙げられたが、胸腔鏡挿入角度の制限 の改良が最も望まれる。本邦で開発された準ロボット手術として今後に期待したい。 


\title{
RV4-3
}

\section{Single-port robotic surgery for mediastinal tumor}

\author{
○石川 紀彦、小田 誠、渡邊 剛
}

ニューハート・ワタナベ国際病院 呼吸器外科

【はじめに】近年, 内視鏡外科手術はさらなる低侵襲化を目指し様々な手技, デバイスの開発がなされている. 手技関連としては単項式内視鏡手術の開発であり。デバイス関連としては手術支援ロボットが究極のものと 言える. 今回我々は縦隔腫瘍に対して da Vinci surgical system を用いた世界初の Single-port robotic surgery を施行したので報告する。【症例】50 歳男性. 甲状腺腫瘤の術前精查目的の頸胸部 CT 検査で前縦隔腫瘍を 指摘された，胸腺囊胞を疑い甲状腺と共に一期的に切除する方針となり，縦隔腫瘍切除は da Vinciを用いて 切除を行った，全身麻酔，分離肺換気，左半側臥位とし甲状腺切除後，右前腋窩線上第 3 肋間に $2.5 \mathrm{~cm}$ のポー 卜創を作成．患者の左側より da Vinci S を導入し，同部位にカメラ用 $12 \mathrm{~mm}$ ポート，鉗子用 $8 \mathrm{~mm}$ ポート $(2$ 本）を挿入した。ポート創でロボット鉗子は交差させ，左手の鉗子は右手で，右手の鉗子は左手で操作でき るようにコンソールのスイッチをセッティングした (cross arm technique).【結果】鉗子は互いに干渉する ことなく縦隔腫瘍切除を施行することができた、【結語】ダビンチを用いることで鉬子の自由度が増し，立体 画像下での繊細な操作が可能であった，術者は逆の鉗子を操作していることを気にすることなく，直感的か つ安全な操作が可能であった. cross arm technique は体外でのアームの干渉を回避することにも有効であっ た．ダビンチを用いた Single-port robotic surgeryはロボット胸部外科手術の新たな可能性を示すものであ る. 


\section{RV4-4}

\section{呼吸器外科領域におけるダヴィンチ Xi サージカルシステム使 用時の工夫}

○須田 隆、栃井 祥子、前田 亮、栃井 大輔、八丸 亜由美、金田 真吏、高木 靖 藤田保健衛生大学 心臟血管外科・呼吸器外科

ダヴィンチサージカルシステム Xi は最も新しいシステムであり、Si システムと異なる点も多いため、まっ たく新しいポートの位置決め、ドッキングの方向の変更が必要になる。当院でのダヴィンチ Xi 使用時の工夫 を供覧する。新しいシステムは、側方からドッキングできるため、麻酔科に十分なワーキングスペースが確 保できることが大きな利点である。ダブルバイポーラ（両手ともバイポーラ装着）が可能なこと、ボタン一 押しで、エンドスコープの視野を $30^{\circ}$ 上下に変更することが可能となり、アームの可動域も増大したことに より、カメラの挿入位置をより頭側に配置できるため、頭側の視野が良くなったこと、第 5 肋間の創から未 診断腫瘤の触診が可能になったこと、アームが細くなったため、アーム間の干渉が少なくなり、助手が操作 するスペースを確保しやすくなったこと、ポート間が比較的狭くてもアーム間が干渉しにくいことおよび、 ポートホップ機能により、肺を圧排することなく別の視野からのターゲットの視認が可能になったことも利 点である。ポート挿入時に使用する胸腔鏡と付属機器の代わりにロボットのエンドスコープが使用可能なこ とも利点とされるが、画面の上下が制御されているため、助手側モニター反転法で行っている施設は注意が 必要である。SI システムには搭載されたベッセルシーリングシステムやドゥベーキー摂子が現時点でないこ と、海外では承認されているステープラーがまだ付かないことが問題点としてあげられる。Xi システムの特 性に合わせた手術手技の工夫が必要である。 
RV4-5

\section{縦隔腫瘍に対するロボット支援手術の実際}

○三和 健、大島 祐貴、万木 洋平、若原 誠、松岡 佑樹、荒木 邦夫、谷口 雄司、中村 廣繁 鳥取大学医学部附属病院 胸部外科

本邦では 2009 年のロボット支援手術の薬事承認以来 5 年が経過した。呼吸器外科ではいまだ限定的な発展 にすぎないが、当科ではこれまで安全性、効率性を意識し、症例を積み重ね、良好な成績を得ている。最近 の手術の実際についてビデオを供覧する。当科で 2015 年 11 月までに縦隔腫瘍に対して 36 例のロボット支援 手術を経験した。内訳は胸腺腫 9 例、胸腺腫 + 重症筋無力症 (MG） 9 例、MG5 例、胸腺癌 1 例、Castleman 病 1 例、胸腺囊腫 1 例、成熟型奇形腫 1 例、食道良性腫瘍 3 例、神経原生腫瘍 4 例。全例 3 アームで行い、 手術時間は 186 分、コンソール時間 134 分、出血量 $5 \mathrm{gram}$ (いずれも中央值)、G3 以上の合併症は 2 例（乳 糜胸、MGクリーゼ）に認めた。ドレーン留置は 1 日で術後在院日数 5 日（いずれも中央值）。ロールインは 当初真横からで、現在は斜め（30 度）からのドッッキングとしている。最近は CO2 送気下の手術を基本と し、CO2 圧は 5-10mmHg で、エアーシールの使用は安定圧、排煙、良好なアシストに寄与する。またVessel sealerによる血管処理で手術の安全性・効率性が向上した。タイルプロ機能による術中ナビゲーションを使 用、Dual console 操作ではポインターで操作部位を示し、Swap 機能を用いてパート・パートで指導医と操作 を交代している。特に大きな胸腺腫、拡大胸腺摘出術、食道腫瘍に有用性を感じており、これまで $8 \mathrm{~cm}$ を超 える腫瘍や心膜再建も経験した。最新論文でロボット手術中に視野外でのトラブルが多いと報告された。視 野外でのアーム操作が要因のひとつである。縦隔腫瘍手術では、アームによる胸壁の損傷、血管損傷などに 注意を払う必要がある。 
RV4-6

\section{不全分葉肺に対するロボット支援下右下葉切除術の 1 例}

○福井 高幸、川口 晃司、中村 彰太、福本 紘一、羽切 周平、尾関 直樹、杉山 燈人、岡阪 敏樹、 横井 香平

名古屋大学 呼吸器外科

【背景】葉間で肺動脈を露出することができない不全分葉肺に対する肺葉切除は、肺動脈に到達するまでに工 夫を要する。今回、右中下葉間、上下葉間が分葉不全である下葉原発の肺癌症例に対し、ロボット支援下に 下葉切除術を施行した 1 例を経験したのでビデオで供覧する。【症例】 51 歳非喫煙女性。検診胸部 X 線写真 で右肺に結節影を指摘され、CT で右肺 $\mathrm{S} 9 / 10$ に $2.5 \mathrm{~cm}$ 大の mixed GGO を認めた。画像上原発性肺癌が疑わ れるため手術を施行した。【手術】第 8 肋間中腋窩線上にカメラポート、ダビンチは 2 アーム、助手用ポート 2 個の計 5 ポートを扦入した。助手用ポートからエアシールで CO2 送気を行った $(6 \mathrm{mmHg})$ 。胸腔内には癒 着・播種は認めなかった。上下葉間は分葉なく、中下葉間も分葉不全であった。肺勒帯を切離して下肺静脈 を確保後、葉間にて肺動脈の露出を複数箇所で試みたが到達することができなかった。そこでまず下肺静脈 を切離して下葉を頭側に讳引・展開し、気管支を下から見上げて同定した。下葉気管支を切離し、その裏側 に現れた肺動脈のうち下葉への分岐を確認してこれを切離した。最後に葉間を切離して下葉切除を行った。 手術時間は 4 時間 28 分、コンソール 3 時間 54 分、出血量 $11 \mathrm{~g}$ であった。【結語】ロボット支援下手術のメリッ トである多方向からの鉬子操作および 3D 視野を駆使し、不全分葉肺に対する肺葉切除を完遂し得た。 